\title{
Manajemen Hubungan Masyarakat untuk Meningkatkan Citra Pendidikan Tinggi Terbuka dan Jarak Jauh Melalui Media Sosial di Universitas Terbuka
}

\author{
Mega Suteki \\ Wonoasri Education Center \\ Email: megasuteki@gmail.com
}

\begin{abstract}
Abstrak
Latar belakang penelitian ini adalah munculnya metode hubungan masyarakat baru melalui media sosial di dunia pendidikan. Tujuan penelitian ini adalah untuk mendeskripsikan dan menganalisis manajemen hubungan masyarakat dalam meningkatkan citra pendidikan tinggi terbuka dan jarak jauh melalui media sosial di Universitas Terbuka; dan mendeskripsikan serta menganalisis faktor yang menghambat manajemen hubungan masyarakat dalam meningkatkan citra pendidikan tinggi terbuka dan jarak jauh melalui media sosial di Universitas Terbuka. Metode penelitian yang digunakan adalah metode kualitatif. Metode ini digunakan untuk menghasilkan hasil data deskriptif. Teknik pengumpulan data menggunakan wawancara, dan dokumen serta menggunakan analisa data kualitatif model interaktif Miles, Hubberman dan Saldana. Hasil temuan di lapangan menunjukkan bahwa perencanaan kegiatan hubungan masyarakat di UPBJJ-UT dibuat berdasarkan pedoman yang dibuat di Universitas Terbuka pusat. Pengorganisasian kegiatan hubungan masyarakat di UPBJJ-UT Surabaya mencakup pengaturan anggota staf dalam mengelola akun media sosial dan website; Koordinasi mencakup pengaturan struktur staf dan pendelegasian kerja; Komunikasi dilakukan secara internal dan eksternal; Pelaksanaan program dibagi menjadi program rutin dan program insidental; Pengawasan dilakukan oleh koordinator dan Kepala UPBJJUT Surabaya; Fungsi modifikasi dilaksanakan melalui rapat evaluasi; Hambatan internal berupa penguasaan teknologi informasi mahasiswa yang beragam dan beban kerja staf yang berat. Sedangkan hambatan eksternal adalah infrastruktur jaringan internet.
\end{abstract}

Kata Kunci: Citra Universitas, Hubungan Masyarakat, Media Sosial, Pembelajaran Terbuka dan Jarak Jauh

\begin{abstract}
Background of the research is that a new public relation strategy through social media emerged in education institutions. Indonesia Open University as the biggest holder of open and distance learning in higher education has limit to provide time and place for student to meet each other. Due to the reason, Indonesia Open University needs to use most effective and efficient way to reach student and improving image at the same time. Public relation activity consist of planning, organizing, coordinating, communicating, actuating, controlling, and modificating. Some problems are determined: how to manage public relation activity to improve the image of open and distance learning in higher education through social media?; what factors are thwarting the public relation activity to improve the image of open and distance learning in higher education through social media? Method of the research is qualitative. Data presented with descriptive text, pictures, and tables. Data collection techniques include interview and documentary study. Data analysis tool is interactive model qualitative by Miles, Hubberman, and Saldana (2014). Result of the research indicate that public relation activity planning on distance learning program unit in Surabaya was made based on guidelines made by Indonesia Open University. Organizing activity include organizing staffs to manage website and sosial media accounts. Coordinating activity include making staffs working structure and describe job descriptions. Communicating activity done internally and externally. Activity programs include routine programs and incidental programs. Controlling activity performed by Coordinators and Head of Distance Learning Program Unit. Modification function performed through evaluation meeting. Internal factors which thwarting public relation activity are student's different level of mastering information technology and the responsibilty to manage many social media accounts is a strain on the staffs. Besides, external factor is infrastructure related to internet.
\end{abstract}

Keywords: Open And Distance Learning, Public Relation, Social Media, University Image

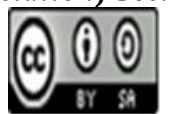

\begin{tabular}{|l|l|l|} 
Received: November 4, 2020 & Revised: March 30, 2021 & Acepted: March 31, 2021
\end{tabular} 


\section{Pendahuluan}

Dunia pendidikan yang berkembang secara dinamis tidak dapat terlepas dari pengaruh teknologi informasi yang semakin cepat. Institusi pendidikan tinggi dituntut untuk dapat berkembang mengikuti kebutuhan masyarakat melalui teknologi informasi secara efektif dan efisien. Seiring dengan perkembangan teknologi informasi yang semakin cepat, kompetisi antar perguruan tinggi menjadi semakin ketat. Perguruan tinggi yang berbeda bersaing untuk mendapatkan calon mahasiswa yang potensial dan mempertahankan eksistensi sebagai institusi yang terbaik di mata masyarakat. Perguruan tinggi dituntut terus membangun dan memelihara komunikasi yang baik dengan masyarakat.

Di sisi lain, terbitnya aturan-aturan dan pilot project dalam konstelasi pendidikan jarak jauh secara legal-formal semakin mengukuhkan keberadaan sistem pendidikan jarak jauh sebagai bagian integral dalam pendidikan nasional. Terbitnya aturan-aturan tersebut memberikan peluang bagi perguruan tinggi negeri maupun swasta baik sendiri maupun bersama-sama untuk menyelenggarakan pendidikan jarak jauh. Dalam hal ini, Universitas Terbuka bukan lagi satusatunya penyelenggara pendidikan terbuka dan jarak jauh di Indonesia. Sebagai institusi pendidikan yang menyediakan jasa pendidikan terbuka dan jarak jauh, Universitas Terbuka menemui kendala jarak dan terbatasnya kesempatan bertemu antar mahasiswa dengan mahasiswa maupun dosen dengan mahasiswa.

Hal ini menyebabkan Universitas Terbuka membutuhkan aktivitas manajemen hubungan masyarakat yang efektif sebagai alat untuk meningkatkan citra perguruan tinggi di mata stakeholder. Salah satu unsur penting dalam memenangkan persaingan antara perguruan tinggi yang menyelenggarakan pendidikan terbuka dan jarak jauh adalah melalui peningkatan citra perguruan tinggi. Citra adalah serangkaian kepercayaan yang dihubungkan dengan sebuah gambaran yang dimiliki atau diperoleh dari pengalaman (Alma, B., 2008). Larkin (Haris, 2012) memberikan pendapat bahwa citra atau reputasi merefleksikan bonafiditas nama suatu perusahaan menurut pandangan lembaga atau kelompok tertentu yang berkepentingan terhadap perusahaan tersebut.

Dalam temuan penelitiannya, Mulyana (Mulyana, 2011) mengemukakan bahwa citra positif institusi dalam jasa pendidikan dapat digunakan sebagai instrument positioning untuk mempengaruhi pemilihan lembaga pendidikan tinggi oleh calon mahasiswa. Citra institusi tersebut akan membentuk dan mempertahankan loyalitas mahasiswa dan masyarakat terhadap lembaga pendidikan tinggi tersebut. Aghaz et al., (Aghaz, Hashemi, \& Sharifi Atashgah, 2015) mengemukakan hal senada bahwa citra perguruan tinggi memberikan pengaruh signifikan terhadap tingkat kepercayaan dan loyalitas mahasiswa pada institusi perguruan tinggi. Sebagai salah satu alat untuk melaksanakan kegiatan hubungan masyarakat, penggunaan media sosial memudahkan mahasiswa mengikuti video-video pelatihan dan melakukan sesi tanya jawab dengan pengajar. Selain itu, pemberian ucapan pada laman media sosial Universitas juga meningkatkan citra positif Universitas di mata mahasiswa (Elitaş, 2015).

Penelitian oleh Stefko et al., (Štefko, Fedorko, \& Bačík, 2015) dan Khan (Khan, 2013) memberikan gambaran bahwa terdapat kebutuhan dari masyarakat untuk mendapatkan informasi tentang lembaga pendidikan tinggi secara mudah dan cepat melalui media sosial dan laman web. Penelitian terdahulu belum memaparkan mengenai manajemen hubungan masyarakat dalam penyelenggaraan pendidikan tinggi terbuka dan jarakjauh di Indonesia. Berdasarkan paparan latar belakang tersebut, penelitian ini bertujuan menjelaskan mengenai manajemen hubungan masyarakat serta faktor penghambat dalam meningkatkan citra pendidikan tinggi terbuka dan jarak jauh melalui media sosial di Universitas Terbuka. 


\section{Metode Penelitian}

Metode penelitian yang digunakan adalah metode kualitatif. Metode ini digunakan untuk menghasilkan hasil data deskriptif. Penelitian ini menggunakan analisa data kualitatif model interaktif Miles, Hubberman dan Saldana (Miles, M. B., Hubberman, A. M., \& Saldana, 2014). Tahapan analisis dalam penelitian ini terdiri dari tiga tahapan pokok yakni meringkas data, menyajikan data, dan penarikan kesimpulan. Penelitian ini dilakukan di Unit Program Belajar Jarak Jauh Universitas Terbuka Surabaya. UPBJJ-UT Surabaya dipilih sebagai lokasi penelitian karena dianggap dapat mewakili lembaga penyelenggara pendidikan tinggi terbuka dan jarak jauh di Indonesia. Metode pengumpulan data yang digunakan oleh peneliti adalah wawancara mendalam dan studi dokumenter. Penentuan informan dalam penelitian ini menggunakan purposive sampling. Informan utama dalam penelitian ini adalah Kepala UPBJJ-UT Surabaya yang dinilai mengetahui dan menguasai mengenai hal-hal yang berkaitan dengan manajemen hubungan masyarakat melalui media sosial di UPBJJ-UT Surabaya. Berdasarkan informasi dari informan utama tersebut, peneliti menindaklanjuti dengan menetapkan informan berikutnya yakni Coordinator of learning support \& learning material service UPBJJ-UT Surabaya, Administrator media sosial dan website UPBJJ-UT Surabaya, Pengurus kelompok belajar UPBJJ-UT Surabaya, dan Mahasiswa Universitas Terbuka.

\section{Hasil Penelitian dan Pembahasan}

\section{Hubungan Masyarakat di Perguruan Tinggi}

Istilah hubungan masyarakat (public relations) sering tercampur dengan istilah pemasaran. Ada yang menyebut perbedaan itu terletak pada penggunaan istilah pemasaran yang digunakan pada organisasi yang mencari laba, dan hubungan masyarakat digunakan oleh organisasi yang tidak mencari laba (Alma, B., 2008). Namun pada kenyataannya istilah pemasaran juga banyak dipakai oleh organisasi non-profit, dan istilah hubungan masyarakat juga digunakan oleh organisasi yang mencari laba. Pendapat Ryans (Alma, B., 2008) menyebutkan bahwa pemasaran tidak sama dengan hubungan masyarakat, namun semua fungsi tersebut memiliki tujuan untuk memberikan pelayanan. Pada dasarnya pemasaran muncul tidak untuk memenuhi kepentingan lembaga itu sendiri, namun untuk memberikan kepuasan kepada konsumen. Kotler (Kotler, 1987) juga memberikan pendapat mengenai perbedaan pemasaran dan hubungan masyarakat, hubungan masyarakat memiliki fungsi pokok sebagai alat komunikasi, sedangkan pemasaran mencakup evaluasi kebutuhan, pengembangan produk, distribusi serta penentuan tarif..

Lembaga pendidikan sebagai organisasi tidak akan dapat terlepas dari aktivitas hubungan masyarakat. Dalam hal ini, lembaga pendidikan tidak hanya berhubungan dengan pelanggan jasa pendidikan, pemasok jasa pendidikan, dan perantara jasa pendidikan, lembaga pendidikan melakukan aktivitas ini dengan masyarakat yang lebih luas. Aktivitas hubungan masyarakat biasanya dilakukan dengan menggunakan pendekatan melalui berbagai aspek. Cutlip (Cutlip, S. M., Center A. H., \& Broom, 2006) mengungkapkan bahwa aspek-aspek penting yang harus diperhatikan oleh praktisi hubungan masyarakat meliputi,

a) Pembingkaian pesan, yaitu bagaimana memilih dan menulis pesan yang akan disampaikan kepada khlayak sasaran melalui media sosial?

b) Nilai berita, yakni apakah berita dan informasi yang disampaikan melalui media sosial memiliki nilai berita yang menarik perhatian khalayak sasaran dan media massa?

c) Semiotika, yakni apakah pesan dan informasi yang disampaikan melalui media sosial memiliki arti yang jelas dan tidak ambigu?

d) Simbol, yakni simbol-simbol apa yang digunakan dalam melakukan kegiatan hubungan masyarakat?

e) Stereotip, yakni citra apa yang ingin ditimbulkan dan ditonjolkan melalui kegiatan hubungan masyarakat? 


\section{Mega Suteki \\ Manajemen Hubungan Masyarakat untuk Meningkatkan Citra Pendidikan Tinggi Terbuka dan Jarak Jauh Melalui Media Sosial di Universitas Terbuka}

Hal ini dilakukan untuk membangun pemahaman masyarakat tentang aktivitas pemasaran jasa pendidikan. Aktivitas hubungan masyarakat dalam lembaga pendidikan mencakup usaha yang sistematis untuk membentuk dan memelihara sikap saling percaya antara lembaga pendidikan dan lingkungan masyarakat (Lockhart, 2005).

\section{Pendidikan Terbuka dan Jarak jauh}

Sistem pendidikan jarak jauh yang dipersepsikan sebagai inovasi abad 21 merupakan sistem pendidikan yang memiliki daya jangkau luas, lintas ruang, waktu, dan sosioekonomi. Sistem pendidikan jarak jauh membuka akses terhadap pendidikan bagi siapa saja, di mana saja, dan kapan saja. Karakteristik pendidikan jarak jauh ini membuat sistem pendidikan jarak jauh dianggap sebagai solusi terhadap masalah pendidikan yang berkaitan dengan pemerataan dan demokratisasi pendidikan.

Perkembangan ilmu pengetahuan dan teknologi dewasa ini telah berkembang dengan sangat pesat. Tersebarnya informasi menjadi semakin cepat menembus jarak, ruang, dan waktu. Pendidikan juga tidak luput terpengaruh oleh perkembangan tersebut sehingga muncul distance learning yang memanfatkan sistem informasi dan komunikasi untuk kepentingan pemerataan pendidikan. Pembelajaran dengan memanfaatkan teknologi informasi dan komunikasi tidak menuntut pendidik dan mahasiswa berada pada satu tempat dan waktu. Melainkan dapat dilakukan di berbagai tempat yang berbeda.

Melalui teknologi informasi dan komunikasi, ada suatu peningkatan keterhubungan orng dalam bidang pendidikan. Lingkungan global dipandang dalam beberapa hal untuk menjadi jawaban terhadap kemiskinan dan permasalahan lain melalui meningkatnya peluang belajar yang terdistribusi (Munir, 2009). Model web-enchanced course menjadikan internet sebagai penyedia sumber belajar yang bisa diakses online. Internet juga menjadi sarana bagi peserta didik untuk meningkatkan komunikasi, baik sesama peserta didik, peserta didik dengan pengajar, atau peserta didik dengan kelompok lain diluar institusi sekolah. Dalam pendidikan terbuka dan jarak jauh, internet bukan hanya berperan sebagai pendukung kegiatan pengajaran melainkan juga faktor utama yang menentukan jalannya pengajaran.

Pendidikan terbuka dan jarak jauh mempunyai karakteristik bersifat terbuka, belajar mandiri, belajar tuntas, menggunakan teknologi informasi dan komunikasi, menggunakan teknologi pendidikan lainnya dan/atau pembelajaran terpadu perguruan tinggi. Penyelenggaraan program distance learning dilandasi pada prinsip pendidikan terbuka dan pendidikan jarak jauh (Universitas Terbuka, 2010). Pada model pendidikan terbuka dan jarak jauh, pengajar dan peserta didik terpisah oleh waktu dan ruang. Walaupun demikian diskusi masih bisa dilaksanakan, baik secara sinkron maupun asinkron. Seluruh kegiatan pengajaran dilakukan melalui internet sehingga kegiatan tatap muka secara fisik tidak diperlukan (Universitas Terbuka, 2010)

\section{Citra di Perguruan Tinggi}

Bernskin (Bernskin, 1984) berpendapat bahwa citra adalah gambaran yang ada dalam benak seseorang. Haris (Haris, 2012) memberikan pendapat bahwa citra suatu perguruan tinggi merupakan faktor dalam meningkatkan daya saing dan merupakan salah satu elemen kunci intangible resources yang akan menjadi sumber dari penciptaan kondisi keunggulan daya saing berkelanjutan (sustainable competitive advantage) suatu lembaga. Citra tersebut diperoleh dari serangkaian kemampuan dan pengalaman yang terakumulasi, sehingga perguruan tinggi tersebut memiliki kinerja terbaik bagi stakeholder.

Terkait dengan membentuk citra pada perguruan tinggi sebagai sebuah organisasi, merek merupakan suatu elemen penting dalam menentukan tema periklanan. Memiliki branding yang kuat merupakan aspek yang berharga untuk bertahan di tengah persaingan antar perguruan tinggi. Dalam meningkatkan citra perguruan tinggi, pemasaran merek merupakan simbol penggambaran seluruh informasi mengenai jasa dan produk yang dihasilkan oleh perguruan tinggi. Merek pada perguruan tinggi biasanya terdiri dari nama, logo, dan seluruh elemen visual lainnya seperti 
gambar, tipografi, warna, dan simbol. Merek juga merupakan visualisasi dari citra yang ingin ditanamkan pada benak konsumen (Haris, 2012). Meningkatkan citra merupakan salah satu tujuan yang jelas dari kegiatan hubungan masyarakat di perguruan tinggi. Sasaran utama kegiatan hubungan masyarakat di perguruan tinggi adalah menanamkan suatu citra positif kepada publiknya dalam rangka mempertahankan eksistensi dan memperoleh dukungan dari masyarakat.

\section{Media Sosial}

Era teknologi dan informasi saat ini menawarkan media sosial sebagai wadah untuk memenuhi keinginan tersebut. Kaplan dan Henlein (Kaplan \& Haenlein, 2010) memberikan pendapat bahwa definisi media sosial adalah sekelompok aplikasi berbasis internet yang dibangun dengan dasar ide dan teknologi pada Web 2.0 yang memungkinkan pertukaran informasi antar pengguna. Adiputra \& Sulhan (Adiputra \& Sulhan, 2012) juga memberikan pendapat mengenai media sosial. Mereka berpendapat bahwa media sosial merupakan sebuah media online yang memungkinkan para pengguna dapat berpartisipasi dengan mudah. Partisipasi tersebut dapat berupa berbagi informasi, menciptakan isi yang ingin disampaikan, memberi komentar atas masukan yang diterima dan seterusnya.

Adapun bentuk-bentuk media sosial antara lain: Facebook, Twitter, Blog ataupun jejaring sosial lainnya. Lebih jauh Kaplan \& Haenlein (Kaplan \& Haenlein, 2010) juga membuat klasifikasi mengenai jenis-jenis media sosial yakni blogs, collaborative projects, microblogging, social networking sites, content communities, virtual social worlds, dan virtual game worlds. Mayfield (Antony, 2008) juga memberikan pandangan yang mirip dengan Kaplan \& Haenlein. Mayfield mengklasifikasikan media sosial menjadi enam jenis pokok yakni social networks, blogs, wikis, podcast, forums, content communities, dan microblogging.

Tabel 1. Klasifikasi media sosial

\begin{tabular}{cccccc}
\hline & \multicolumn{5}{c}{ Social presence/media richness } \\
\hline & Low & Low-medium & Medium & High \\
\cline { 2 - 5 } & High & blogs & $\begin{array}{c}\text { Micro- } \\
\text { blogging }\end{array}$ & $\begin{array}{c}\text { Social } \\
\text { networking } \\
\text { sites }\end{array}$ & Virtual social world \\
\cline { 2 - 5 } & Low & $\begin{array}{c}\text { Collaborative } \\
\text { projects }\end{array}$ & & $\begin{array}{c}\text { Content } \\
\text { communities }\end{array}$ & Virtual game worlds \\
& & & &
\end{tabular}

Sumber: Kaplan \& Haenlein, 2011

Era sosial media baru yang muncul dengan beragam bentuk memberikan pilihan yang semakin luas bagi masyarakat untuk menggunakannya sebagai alat komunikasi dan berbagi informasi. Dalam jurnal penelitiannya, Elitas (Elitaş, 2015) merangkum munculnya media sosial sebagai sebuah era baru dalam komunikasi, Pada awalnya media sosial muncul pada awal tahun 90-an dengan perangkat lunak bernama mIRC. mIRC memberikan kesempatan bagi sesama pengguna untuk saling bertukar pesan. mIRC menjadi sangat populer dan menandai awal munculnya penggunaan media sosial secara luas. Pada akhir tahun 90-an, media sosial yang awalnya hanya memberikan ruang untuk bertukar pesan berubah bentuk menjadi berupa blog dan microblog. Hal ini membuktikan bahwa media sosial tidak hanya dapat digunakan untuk berkomunikasi, tapi juga untuk mendapatkan informasi. 


\section{Mega Suteki \\ Manajemen Hubungan Masyarakat untuk Meningkatkan Citra Pendidikan Tinggi Terbuka dan Jarak Jauh Melalui Media Sosial di Universitas Terbuka}

\section{Manajemen Hubungan Masyarakat untuk Meningkatkan Citra Pendidikan Tinggi Terbuka dan Jarak Jauh melalui Media Sosial}

Pentingnya citra bagi pendidikan tinggi dipaparkan oleh Nguyen dan LeBlanc (Nguyen, Nha; LeBlanc, 2001). Temuan penelitian menunjukkan bahwa derajat loyalitas mahasiswa cenderung lebih tinggi ketika persepsi dan citra perguruan tinggi sesuai dengan harapan mahasiswa. Hubungan antara keduanya juga mempengaruhi loyalitas mahasiswa. Hal yang dapat dilakukan untuk meningkatkan citra tesebut salah satunya adalah melalui kegiatan hubungan masyarakat. Ketika melaksanakan program kerjanya, praktisi hubungan masyarakat menggunakan konsep manajemen. Tujuannya adalah untuk memudahkan pelaksanaan tugas dan mendukung semua tahapan pekerjaan pada hubungan masyarakat (Gassing \& Suryanto, 2016). Tahapan tugas tersebut mencakup planning, organizing, coordinating, communicating, actuating, controlling, evaluating, dan modificating (Mustari, 2014)

Planning, tujuan perencanaan kegiatan hubungan masyarakat di UPBJJ-UT Surabaya yakni agar mahasiswa lebih mudah dalam menjangkau informasi yang mereka butuhkan terkait kegiatan di Universitas Terbuka. Dalam hal ini khalayak sasaran adalah mahasiswa yang memerlukan media untuk mendapatkan informasi dengan mudah dan cepat. Jangkauan media sosial yang luas serta murah dianggap cocok untuk tujuan tersebut. Strategi yang dilakukan oleh UPBJJ-UT Surabaya dalam melaksanakan kegiatan hubungan masyarakat meliputi pembuatan pesan yang jelas dan dapat menarik perhatian masyarakat untuk membaca informasi tersebut lebih lanjut. Pesan yang telah dibuat kemudian dievaluasi melalui diskusi Kepala UPBJJ-UT Surabaya dengan staf dan Koordinator. Media yang digunakan untuk penyampaian pesan tersebut adalah melalui akun media sosial dan laman web UPBJJ-UT Surabaya. Pesan yang disampaikan dalam akun media sosial UPBJJ-UT Surabaya tidak hanya informasi yang sifatnya formal, namun juga ucapan dan motivasi bagi mahasiwa.

Hal ini senada dengan pendapat Claudu-Dan (Claudiu-Dan, 2015) yang menyatakan bahwa gambaran penelitian mengenai kegiatan sosialisasi layanan yang disertai dengan data dapat bermanfaat untuk menentukan strategi dalam menghadapi persaingan antar lembaga dalam era internet yang semakin dinamis dan berubah dengan cepat. Namun terdapat perkembangan yang cepat dimana lembaga melakukan kegiatan sosialisasi online dengan memperhatikan tiga isu pokok yakni perencanaan strategis dan workflow, penyimpanan data dan analisis kampanye melalui berbagai saluran termasuk diantaranya saluran digital. Penggunaan saluran digital dianggap lebih murah dan mudah untuk menjangkau calon pengguna layanan.

Organizing, pembagian tugas dalam kegiatan hubungan masyarakat melalui media sosial di UPBJJ-UT bahwa staf pengelola akun media sosial dan website memiliki peran menerbitkan informasi dan berita sekaligus memberikan tanggapan yang cepat dan tepat kepada mahasiswa yang membutuhkan informasi tertentu. Sedangkan koordinator dan Kepala UPBJJ-UT Surabaya memiliki tanggung jawab untuk mengawasi staf.

Coordinating, Dalam melaksanakan tugas-tugas pengelolaan, UPBJJ-UT Surabaya memiliki susunan staf untuk mencapai tujuan. Kepala UPBJJ-UT dibantu oleh Kasubag Tata Usaha, Koodinator Registrasi \& Ujian, dan Koordinator Bantuan Belajar \& Bahan Ajar. Selain koordinator-koordinator, Kepala UPBJJ-UT juga dibantu oleh tenaga dosen dan tenaga administrasi dalam melayani mahasiswa yang berada dalam wilayah jangkauannya. Pelaksanaan fungsi UPBJJ-UT yang berkaitan dengan sosialisasi dan promosi dilakukan dengan melalui aktivitas hubungan masyarakat.

Communicating, manajemen hubungan masyarakat di UPBJJ-UT Surabaya mencakup penyampaian rencana program kepada mahasiswa dan masyarakat baik secara internal dan secara eksternal. Melalui paparan hasil wawancara, dapat diketahui bahwa pengomunikasian rencana program kegiatan hubungan masyarakat kepada staf dilakukan melalui rapat-rapat pengarahan sebanyak minimal sekali dalam satu bulan. Frekuensi rapat dapat berubah-ubah sesuai dengan kondisi dan situasi. Rapat pengarahan tambahan akan diadakan apabila terdapat pengumuman 
khusus dari Universitas Terbuka pusat sehingga diperlukan perubahan rencana atau penyusunan rencana kegiatan baru. Sedangkan secara eksternal, khusus untuk jurusan pendidikan dasar (PGSD dan PG-PAUD), UPBJJ-UT memanfaatkan adanya pengurus pokjar pada masing-masing wilayah untuk menyampaikan informasi dan berita-berita kepada masyarakat dan mahasiswa. Penyampaian rencana program secara eksternal pada jurusan selain pendidikan dasar umumnya dilakukan melalui media sosial dan website UPBJJ-UT Surabaya. Rencana program yang diunggah meliputi kalender akademik, layanan belajar online, katalog jurusan, dan jasa pelayanan lain-lain.

Actuating, Pelaksanaan pencitraan melalui manajemen hubungan masyarakat di UPBJJ-UT Surabaya dilakukan dengan memberikan informasi terkait kegiatan lembaga, kegiatan dosen, dan kegiatan mahasiswa. Penyebaran informasi ini memiliki tujuan untuk memperkenalkan profil Universitas Terbuka secara lebih mendalam kepada masyarakat. Pelaksanaan program hubungan masyarakat ini dibagi menjadi jenis program rutin dan insidental. Pelaksanaan program rutin dilakukan secara terus menerus sesuai dengan rencana awal yang telah dibuat sebelumnya. Program rutin dapat diubah sewaktu-waktu apabila terdapat program kegiatan hubungan masyarakat yang sifatnya insidental. Selain program kegiatan hubungan masyarakat yang sifatnya rutin, UPBJJ-UT Surabaya juga memiliki program kegiatan yang sifatnya insidental. Program kegiatan hubungan masyarakat yang sifatnya insidental ini dilaksanakan pada periode tertentu saja. Program kerja insidental ini cenderung dilaksanakan apabila Universitas Terbuka menyelenggarakan kegiatan yang besar contohnya Dies Natalis dan Wisuda.

Controlling, Aspek pengawasan kegiatan humas di UPBJJ-UT Surabaya dilaksanakan dengan luwes dan tidak kaku. Meskipun pengawasan dilakukan oleh banyak pihak yakni dari pimpinan UPBJJ-UT Surabaya sendiri dan pihak Universitas Terbuka pusat, namun apabila terjadi kesalahan atau perubahan tetap dapat diatasi dengan cepat. Aspek pengawasan kegiatan hubungan masyarakat melalui media sosial di UPBJJ-UT Surabaya dapat diuraikan menjadi dua jenis yakni pengawasan langsung dan tidak langsung. Pengawasan langsung dalam kegiatan hubungan masyarakat di UPBJJ-UT Surabaya dilakukan oleh Kepala UPBJJ-UT Surabaya dan Koordinator UPBJJ-UT Surabaya. Segala unggahan di media sosial dan laman web UPBJJ-UT Surabaya harus melalui persetujuan Kepala dan Koordinator. Hal ini dilakukan untuk menghindari kesalahan dalam informasi yang akan diunggah. Staf humas Universitas Terbuka pusat menuntut staf pengelola akun media sosial dan laman web UPBJJ-UT Surabaya untuk memberikan tanggapan terhadap komentar dan pertanyaan mahasiswa dan masyarakat yang masuk dengan cepat dan tepat. Kepala UPBJJ-UT juga mengungkapkan bahwa selain pengawasan langsung oleh Kepala UPBJJ-UT Surabaya dan Koordinator. Informasi yang diunggah melalui akun media sosial dan laman web diawasi secara tidak langsung oleh Universitas Terbuka pusat untuk menjaga reputasi PTJJ yang diselenggarakan oleh Universitas Terbuka.

Modificating, Aspek modifikasi dalam manajemen hubungan masyarakat di UPBJJ-UT dilaksanakan dengan bentuk rapat evaluasi dan perubahan yang disesuaikan dengan kebutuhan dan kondisi UPBJJ-UT Surabaya. Evaluasi tidak hanya dilakukan melalui rapat yang sifatnya formal saja, evaluasi juga dilakukan melalui arahan-arahan dan percakapan antara para staf yang memiliki tanggung jawab melaksanakan kegiatan kehumasan.

\section{Faktor Penghambat}

Aghaz (Aghaz et al., 2015) menyatakan bahwa terdapat perbedaan antara kondisi empiris dan nilai ideal faktor yang mempengaruhi citra perguruan tinggi. Berdasarkan temuan penelitian tersebut, faktor yang mempengaruhi citra perguruan tinggi dapat berasal dari faktor internal, reputasi internasional, civitas akademika, kurikulum akademik, dan lingkungan perguruan tinggi. Penelitian ini juga menunjukkan bahwa citra perguruan tinggi memberikan dampak yang signifikan terhadap kepercayaan mahasiswa terhadap perguruan tinggi.

Salah satu hambatan internal yang nampak dalam manajemen hubungan masyarakat di Universitas Terbuka berupa heterogenitas dalam penguasaan teknologi informasi mahasiswa. 
Heterogenitas penguasaan teknologi pada mahasiswa menyulitkan UPBJJ-UT untuk total melaksanakan kegiatan hubungan masyarakat melalui media sosial. UPBJJ-UT Surabaya dituntut untuk menggunakan metode lain selain melalui media sosial untuk menyampaikan informasi kepada mahasiswa yang kemampuan dalam menggunakan teknologi masih kurang. Penelitian oleh Hall \& Witek (Hall \& Witek, 2016) memaparkan bahwa sosialisasi melalui media internet mengalami peningkatan sehingga eksistensi Universitas di sosial media dianggap perlu untuk membentuk citra dan memperkenalkan layanan yang disediakan Unversitas kepada masyarakat. Namun sosialisasi melalui sosial media bukan satu-satunya metode yang digunakan oleh Universitas. Metode yang paling efektif dalam melakukan sosialisasi layanan didapat dari website resmi, event, open-days, dan representatif dari Universitas yang dilakukan secara bersamaan.

Jumlah mahasiswa yang besar dan heterogen juga berdampak pada beban kerja yang berat bagi staf untuk terus mengawasi akun media sosial UPBJJ-UT. Staf harus dapat memberikan tanggapan secara cepat apabila terdapat mahasiswa atau masyarakat yang membutuhkan informasi tertentu. Sedangkan jumlah staf terbatas. Hal ini memerlukan komitmen perguruan tinggi dalam menyediakan sumber daya untuk mengelola akun media sosial. Pentingnya komitmen pergurua tinggi dalam menyediakan sumber daya dipaparkan oleh Khan (Khan, 2013) bahwa terdapat permintaan yang jelas dari masyarakat untuk mendapatkan informasi mengenai perguruan tinggi melalui sosial media sehingga perguruan tinggi dituntut untuk memiliki kesiapan dalam menyediakan informasi tersebut. Perguruan tinggi harus dapat menyediakan sumber daya yang mencukupi dalam membuat rencana strategis yang jelas untuk menggunakan sosial media sebagai salah satu media penyedia informasi utama mengenai layanan di perguruan tinggi

Infrastruktur jaringan internet. Selain hambatan internal, muncul pula hambatan eksternal yang berhubungan dengan infrastruktur jaringan internet. Jaringan internet yang dapat diandalkan menjadi kebutuhan untuk mengakses infromasi dan mengelola akun media sosial UPBJJ-UT Surabaya. Solusi ketika terjadi ganggungan jaringan internet, maka staf front-desk sebagai pengelola media sosial dan website mengarahkan mahasiswa dan masyarakat yang membutuhkan informasi untuk menggunakan media SMS atau telpon. Mahasiswa yang membutuhkan infromasi juga dapat datang langsung ke kantor UPBJJ-UT Surabaya.

\section{Kesimpulan}

Berdasarkan hasil penelitian dan pembahasan yang telah diuraikan pada bab sebelumnya, maka dapat ditarik kesimpulan sebagai berikut, Planning, Perencanaan kegiatan hubungan masyarakat di UPBJJ-UT dibuat berdasarkan pedoman yang dibuat di Universitas Terbuka pusat. Pedoman ini kemudian disesuaikan dengan kebutuhan UPBJJ-UT Surabaya menjadi sebuah rencana kegiatan, termasuk kegiatan hubungan masyarakat melalui media sosial. Organizing, Pengorganisasian kegiatan hubungan masyarakat di UPBJJ-UT Surabaya mencakup pengaturan anggota staf dalam mengelola akun media sosial dan website, sumber daya yang dibutuhkan, serta pemantauan kinerja staf oleh Kepala UPBJJ-UT Surabaya. Pengaturan tugas staf untuk mengelola akun media sosial dan website UPBJJ-UT Surabaya dibagi menjadi 3 orang staf. 2 staf front-desk bertugas mengelola serta membalas pesan-pesan dan pertanyaan yang masuk dari mahasiswa dan masyarakat ke akun media sosial UPBJJ-UT Surabaya dan 1 orang staf ICT memiliki tugas mengelola website UPBJJ-UT Surabaya. Pemantauan kinerja staf pengelola akun media sosial berada pada tanggung jawab Koordinator. Coordinating, Struktur organisasi di UPBJJ-UT Surabaya dimulai dari Rektor Universitas Terbuka. Kepala UPBJJ-UT dibantu oleh Kasubag Tata Usaha, Koodinator Registrasi \& Ujian, dan Koordinator Bantuan Belajar \& Bahan Ajar. Selain koordinator-koordinator, Kepala UPBJJ-UT juga dibantu oleh tenaga dosen dan tenaga administrasi. Susunan organisasi dalam pengelolaan media sosial dan website adalah Kepala UPBJJ-UT Surabaya sebagai penanggung jawab, kemudian terdapat 2 koordinator di bawah Kepala UPBJJ-UT Surabaya. Koordinator yang bertugas mengelola akun media sosial dan website 
UPBJJ-UT Surabaya sekaligus melakukan kegiatan kehumasan adalah Coordinator of Learning Support \& Learning Material. Communicating, Aspek communicating dalam manajemen hubungan masyarakat di UPBJJ-UT Surabaya mencakup penyampaian rencana program kepada mahasiswa dan masyarakat baik secara internal dan secara eksternal. Penyampaian rencana program secara internal dilakukan melalui rapat dan pengarahan. Penyampaian rencana program humas secara eksternal UPBJJ-UT Surabaya menggunakan media sosial dan website. Actuating, Aspek pelaksanaan kegiatan manajemen humas di UPBJJ-UT Surabaya merupakan tindakan menjalankan program sesuai dengan rencana yang telah dibuat. Pelaksanaan kegiatan ini dilakukan dengan berpedoman kepada rencana yang telah disetujui bersama oleh pimpinan UPBJJ-UT Surabaya. Pelaksanaan program humas di UPBJJ-UT Surabaya dibagi menjadi program rutin dan program insidental. Controlling, Pengawasan dilakukan oleh koordinator dan Kepala UPBJJ-UT Surabaya. Setelah bahan diunggah ke akun media sosial dan website UPBJJUT Surabaya, unggahan masih dipantau oleh koordinator dan Kepala UPBJJ-UT Surabaya. Unggahan juga dipantau oleh staf Universitas Terbuka pusat. Aspek pengawasan kegiatan humas di UPBJJ-UT Surabaya dilaksanakan dengan luwes dan tidak kaku. Modificating, Fungsi modifikasi dalam manajemen hubungan masyarakat di UPBJJ-UT dilaksanakan dengan bentuk rapat evaluasi dan perubahan yang disesuaikan dengan kebutuhan dan kondisi UPBJJ-UT Surabaya. Evaluasi tidak hanya dilakukan melalui rapat yang sifatnya formal saja, evaluasi juga dilakukan melalui percakapan santai antar staf.

\section{Daftar Pustaka}

Adiputra, W. M., \& Sulhan, M. (2012). Media Baru: Studi Teoritis dan Telaah dari Perspektif Politik dan Sosiokultural. Yogyakarta: FISIPOL Universitas Gadjah Mada.

Aghaz, A., Hashemi, A., \& Sharifi Atashgah, M. S. (2015). Factors contributing to university image: the postgraduate students' points of view. Journal of Marketing for Higher Education, 25(1), 104-126. https://doi.org/10.1080/08841241.2015.1031314

Alma, B., \& H. R. (2008). Manajemen Corporate dan Strategi Pemasaran Jasa Pendidikan Fokus pada Mutu dan Layanan Prima. Bandung: Alfabeta.

Antony, M. (2008). What is Social Media? London: iCrossing.

Bernskin, D. (1984). Company Images and Reality: A Critique Corporate Communications. New York. New York: Holt, Rinehart, and Winston.

Claudiu-Dan, G. (2015). Internet Involvment and Metrics in Adult Education Services Online Marketing in Romania. An Evaluation Study. Procedia Computer Science, 65, 950-960. https://doi.org/10.1016/j.procs.2015.09.067

Cutlip, S. M., Center A. H., \& Broom, G. M. (2006). Effective Public Relation. Jakarta: Kencana Prenada Media Group.

Elitaş, T. (2015). Social Media Usage by Open Education Faculties: Atatürk University Case. Procedia - Social and Behavioral Sciences, 176, 243-250. https://doi.org/10.1016/j.sbspro. 2015.01.467

Gassing, S., \& Suryanto, S. (2016). Public Relations. Yogayakarta: Andi Publisher.

Hall, H., \& Witek, L. (2016). Conditions, Contemporary Importance and Prospects of Higher Education Marketing on the Example of Polish Universities. Procedia Economics and Finance, 39, 206-211. https://doi.org/10.1016/S2212-5671(16)30314-8

Haris, A. (2012). Strategi Program Humas dalam Pencitraan Perguruan Tinggi Kajian Teori dan Studi Multikasus Implementasi Program Humas. Malang: Penerbitan Universitas Muhammadiyah Malang. 
Kaplan, A. M., \& Haenlein, M. (2010). Users of the world, unite! The challenges and opportunities of Social Media. Business Horizons, 53(1), 59-68. https://doi.org/10.1016/j.bushor. 2009.09.003

Khan, R. H. (2013). Marketing Education Online: A Case study of New Zealand Higher Education Institutions. Procedia - Social and Behavioral Sciences, 103, 637-646. https://doi.org/10.1016/j.sbspro.2013.10.382

Kotler, P. (1987). Strategic Marketing for Nonprofit Organizations. New Jersey: Prentice Hall, Inc.

Lockhart, J. M. (2005). How to Market Your School: A Guide to Marketing, Public Relations, and Communication for School Administrators. New York: Universe Inc.

Miles, M. B., Hubberman, A. M., \& Saldana, J. (2014). Qualitative Data Analysis: A Methods Sourcebook (Edition 3). California: Sage Publication Inc.

Mulyana, A. (2011). Pengaruh Citra Institusi dan Kepuasan Mahasiswa terhadap Loyalitas Mahasiswa Fakultas Ekonomi Universitas Terbuka. Universitas Terbuka, Jakarta.

Munir, M. (2009). Konsep Pembelajaran Jarak Jauh. Bandung: Alfabeta.

Mustari, M. (2014). Manajemen Pendidikan. Jakarta: Raja Grafindo Persada.

Nguyen, Nha; LeBlanc, G. (2001). Image and Reputation of Higher Education Institutions in Students' Retention Decisions. International Journal of Educational Management, 15, 303-311.

Štefko, R., Fedorko, R., \& Bačík, R. (2015). The Role of E-marketing Tools in Constructing the Image of a Higher Education Institution. Procedia - Social and Behavioral Sciences, 175, 431438. https://doi.org/10.1016/j.sbspro.2015.01.1220

Universitas Terbuka. (2010). Rencana Strategis 2010-2021. Jakarta. 